\title{
HUBUNGAN DERIVASI PRIME NEAR-RING DENGAN SIFAT KOMUTATIF RING
}

\author{
Pradita Z. Triwulandari ${ }^{1 \S}$, Kartika Sari ${ }^{2}$, Luh Putu Ida Harini ${ }^{3}$ \\ ${ }^{1}$ Jurusan Matematika, Fakultas MIPA - Universitas Udayana [Email: pradita.zuhriahida@ gmail.com] \\ ${ }^{2}$ Jurusan Matematika, Fakultas MIPA - Universitas Udayana [Email: sarikartika@ unud.ac.id) \\ ${ }^{3}$ Jurusan Matematika, Fakultas MIPA - Universitas Udayana [Email: ballidah@unud.ac.id] \\ ${ }^{\S}$ Corresponding Author
}

\begin{abstract}
Near-rings are generalize from rings. A research on near-ring is continous included a research on prime near-rings and one of this research is about derivation on prime near-rings. This article will reviewing about relation between derivation on prime near-rings and commutativity in rings with literature review method. The result is prime near-rings $N$ are commutative rings if a nonzero derivation $d$ on $N$ hold one of this following conditions: (i) $d([x, y])=[x, y]$, (ii) $d([x, y])=$ $[d(x), y]$, (iii) $d([x, y])=[x, y]$, (iv) $d(x \diamond y)=(x \diamond y)$, (v) $d(x) \diamond y=(x \diamond y)$, (vi) $d(x \diamond y)=$ $d(x) \diamond y$, for all $x, y \in I$, with $I$ is non zero semigroup ideal from $N$.
\end{abstract}

Keywords: commutative ring, derivative, ideal semigroup, prime near-ring

\section{PENDAHULUAN}

Aljabar abstrak atau lebih sering dikenal dengan aljabar modern adalah salah satu cabang ilmu aljabar yang mempelajari struktur aljabar, seperti grup, semigrup, ring atau gelanggang, ideal semigrup, lapangan atau field, dan modul. Ilmu aljabar abstrak berkembang pesat karena penerapan dari bentuk-bentuk aljabar tersebut banyak bermanfaat dalam ilmu lain, seperti bidang fisika, kimia, biologi, dan ilmu komputer. Seperti halnya pada ring yang dapat diterapkan pada teori kriptografi, konsep nearring dapat diterapkan pada beberapa bidang, antara lain dalam bidang komputasi, yaitu dalam teori kriptografi dan teori pengkodean serta pada bidang statistika, yaitu balanced incomplete block design atau yang lebih sering dikenal dengan rancangan acak kelompok tak lengkap seimbang.

Near-ring merupakan generalisasi dari ring. Perbedaannya adalah pada near-ring $N$, himpunan tak kosong $N$ yang dilengkapi dengan operasi pertama yaitu $(N, *)$ haruslah berupa grup akan tetapi tidak harus grup abelian serta $(N, *, \#)$ memenuhi salah satu sifat distributif kanan atau kiri (Pilz, 1983). Pada artikel ini, yang dimaksud dengan near-ring adalah kedua jenis near-ring, baik near-ring kanan maupun near-ring kiri, kecuali disebutkan secara khusus. Selain itu, near-ring $N$ juga mengacu pada nearring yang dilengkapi dengan operasi penjumlahan dan perkalian biasa, kecuali disebutkan secara khusus.

Penelitian mengenai derivasi pada near-ring telah banyak dilakukan, antara lain Bell (1987) yang membahas tentang beberapa syarat cukup near-ring merupakan ring komutatif. Selanjutnya, pada penelitiannya yang lain, Bell (1992) meneliti tentang dua jenis derivasi, yaitu derivasi yang mengawetkan sifat komutatif pada ring maupun near-ring dan derivasi Daif. Lebih lanjut lagi, penelitian mengenai generalisasi pada salah satu jenis derivasi, yaitu $n$-derivasi pada near-ring yang melibatkan semigrup idealnya dilakukan oleh Ashraf (2015). Seiring dengan berkembangnya penelitian mengenai near-ring, penelitian mengenai prime near-ring yang merupakan salah satu jenis near-ring juga turut dikembangkan oleh sejumlah peneliti. Wang (1994) meneliti tentang dua jenis derivasi yang dioperasikan bersama-sama pada sebuah prime near-ring. Selanjutnya, Boua (2012) membahas mengenai syarat cukup yang 
mengakibatkan prime near-ring merupakan ring komutatif dengan melibatkan derivasi pada ideal semigrupnya.

Pada artikel Boua (2012), proses pembuktian teorema yang dihasilkan tidak dijelaskan secara detil. Selain itu, contoh yang disajikan hanya contoh penguat bahwa teorema tidak berlaku apabila near-ring bukanlah prime near-ring. Oleh sebab itu, artikel ini akan mengkaji secara lebih mendalam mengenai hubungan antara derivasi prime near-ring dengan sifat komutatif ring dengan melengkapi bukti-bukti yang telah disajikan Boua (2012) serta memberikan contoh-contoh.

Berikut diberikan teori-teori yang berkaitan dengan artikel tujuan pada artikel

Definisi 1.1 (Howie, 1976) Himpunan tak kosong $A$ dari semigrup $S$ dinamakan ideal semigrup kiri apabila $S A \subseteq A$ dan apabila berlaku sebaliknya maka dinamakan ideal semigrup kanan. Suatu ideal dinamakan ideal semigrup 2-sisi, yang selanjutnya disebut ideal semigrup saja, apabila ideal semigrup tersebut merupakan ideal semigrup kanan sekaligus ideal semigrup kiri.

Definisi 1.2 (Pilz, 1983) Diberikan himpunan tak kosong $N$. Himpunan $N$ yang dilengkapi dengan operasi biner $*$ dan \# dinamakan nearring kanan apabila memenuhi aksioma-aksioma:

1. $(N, *)$ adalah grup (tidak perlu abelian)

2. $(N, \cdot)$ adalah semigrup

3. Untuk setiap $a, b, c \in N$ berlaku $(a * b) \# c=(a \# c) *(b \# c) \quad$ (hukum distributif kanan).

Near-ring kiri didefinisikan dengan cara yang sama.

Seperti halnya pada ring, pada near-ring juga terdapat istilah multiplicative center yang didefinisikan sebagai berikut.

Definisi 1.3 (Boua, 2012) Diberikan near-ring $N$. Himpunan $Z(N)$ dikatakan multiplicative center dari near-ring $N$ apabila $Z(N)=\{x \in N \mid x y=y x$ untuk setiap $y \in N\}$
Selanjutnya, pada near-ring $N$ juga dapat berlaku Lie product, yang dilambangkan dengan $[x, y]$ yang berarti $x y-y x$ dan Jordan product, yaitu $x \diamond y=x y+y x$ dengan $x, y \in N$ (Boua, 2012). Selain itu, juga dikenal istilah derivasi $d$ dari near-ring $N$ ke $N$ seperti halnya pada lapangan atau field bilangan real, yang didefinisikan sebagai berikut.

Definisi 1.4 (Ashraf, 2015) Derivasi pada nearring $N$ adalah pemetaan $d: N \rightarrow N$ yang memenuhi untuk setiap $x, y \in N$ berlaku

atau ekuivalen dengan

$$
d(x y)=d(x) y+x d(y)
$$

$$
d(x y)=x d(y)+d(x) y
$$

Definisi 1.5 (Boua, 2012) Suatu near-ring $N$ dikatakan prime near-ring apabila pada $N$ berlaku untuk setiap $x, y \in N, \quad x N y=\left\{0_{N}\right\}$ mengimplikasikan $x=0_{N}$ atau $y=0_{N}$

Dalam teori mengenai near-ring, terdapat beberapa lemma yang berkaitan dengan topik pada penelitian ini, yaitu.

Lemma 1.6 (Boua, 2012) Diberikan prime nearring $N$ dan ideal semigrup tak nol I dari N. Jika pada $N$ berlaku derivasi tak nol d sedemikian sehingga $d(I) \subseteq Z(N)$ maka $N$ adalah ring komutatif.

Lemma 1.7 (Boua, 2012) Diberikan prime nearring $N$ dan ideal semigrup tak nol I dari N. Jika $x, y \in N$ dan $x I y=\{0\}$, maka $x=0$ atau $y=$ 0 .

\section{METODE PENELITIAN}

Penelitian ini dilakukan dengan mengkaji beberapa literatur berupa buku, jurnal, maupun laporan penelitian yang relevan dengan topik yang dibahas. Langkah awal dalam penelitian ini adalah mempelajari konsep dasar dari aljabar abstrak yang digunakan dalam penelitian, meliputi teori grup dan ring beserta beberapa teori terkait, yaitu semigrup, ideal semigrup beserta contohnya. Mengingat yang dikaji dalam penelitian ini adalah near-ring khususnya pada prime near-ring dan derivasinya, maka langkah 
selanjutnya yang dilakukan adalah mempelajari definisi near-ring, prime near-ring, Jordan product, Lie product, dan derivasi pada nearring. Selanjutnya juga dipelajari sifat-sifat beserta contoh yang terdapat di dalam teori terkait.

Setelah mempelajari semua konsep yang berkaitan, langkah selanjutnya adalah melengkapi bukti setiap teorema dari penelitian Boua (2012). Langkah terakhir adalah memberikan contoh yang terkait dengan teorema tersebut.

\section{PEMBAHASAN}

Pada bagian ini dibahas hubungan antara derivasi prime near-ring dengan sifat komutatif ring seperti yang dipaparkan pada beberapa teorema berikut.

Teorema 3.1 (Boua, 2012) Diberikan prime near-ring $N$ dan ideal semigrup tak nol $I$ dari $N$. Jika $d$ derivasi tak nol pada $N$ yang memenuhi $d([x, y])=[x, y]$, untuk setiap $x, y \in I$, maka $N$ adalah ring komutatif.

\section{Bukti}

Diketahui $N$ prime near-ring, $I$ ideal semigrup tak nol dari $N$ dan $d$ derivasi tak nol pada $N$ yang memenuhi $d([x, y])=[x, y]$, untuk setiap $x, y \in I$. Diambil sebarang $x, y \in I$. Berdasarkan asumsi, berlaku $d([x, y])=[x, y]$. Kemudian dibentuk $x y$ lalu $x y$ disubstitusikan pada $y$ dan menghasilkan

$$
d([x, x y])=[x, x y]
$$

Diperhatikan bahwa berdasarkan definisi Lie product diperoleh $[x, x y]=x[x, y]$. Dengan demikian persamaan (1) menjadi

$$
d(x[x, y])=x[x, y]
$$

Berdasarkan definisi derivasi

$$
d(x[x, y])=x d([x, y])+d(x)[x, y]
$$

Dari persamaan (3) dan asumsi, persamaan (2) dapat ditulis kembali menjadi

$$
\begin{aligned}
& x[x, y]=x[x, y]+d(x)[x, y] \\
\Leftrightarrow & x[x, y]-x[x, y]=d(x)[x, y] \\
\Leftrightarrow & 0=d(x)[x, y] \\
\Leftrightarrow & 0=d(x)(x y-y x) \\
\Leftrightarrow & 0=d(x) x y-d(x) y x
\end{aligned}
$$

$$
\Leftrightarrow d(x) y x=d(x) x y
$$

Selanjutnya, ambil sebarang $z \in N$. Dibentuk $y z$ dan $y z$ disubstitusikan pada $y$ di persamaan (4), sehingga diperoleh $d(x) y z x=$ $d(x) x y z$ yang dapat ditulis kembali menjadi

$$
\begin{aligned}
& d(x) y z x=d(x) y x z \\
\Leftrightarrow & 0=d(x) y x z-d(x) y z x \\
\Leftrightarrow & 0=d(x) y(x z-z x) \\
\Leftrightarrow & 0=d(x) y[x, z]
\end{aligned}
$$

Karena $y$ adalah sebarang elemen pada $I$, maka persamaan (4.5) dapat ditulis menjadi $d(x) I[x, z]=0$. Dari hasil ini dan dengan menggunakan Lemma 1.7, hal ini mengimplikasikan bahwa $d(x)=0$ atau $[x, z]=0$. Karena $d$ adalah derivasi tak nol pada $N$ maka $d(x)=0$ tidak memenuhi. Oleh karena itu berlaku $[x, z]=0$. Hal ini berarti $x z-z x=0 \Leftrightarrow x z=z x$.

Karena $x \in I$ dan $z \in N$, maka berdasarkan definisi $Z(N), x \in Z(N)$. Karena $x \in Z(N)$, maka $d(x) \in Z(N)$ untuk setiap $x \in I$. Hal ini berarti $d(I) \subset Z(N)$. Dari Lemma 1.6, sehingga didapatkan bahwa $N$ merupakan ring komutatif.

Untuk lebih jelasnya, berikut diberikan contoh penerapan dari Teorema 4.1

Contoh 3.2 Diberikan suatu ring komutatif $R$ yang tidak memuat pembagi nol. Himpunan $N=\left\{\left(\begin{array}{cc}a & 0 \\ 0 & 0\end{array}\right) \mid a \in R, a+a=a\right\} \quad$ yang dilengkapi dengan operasi penjumlahan dan perkalian matriks biasa adalah pime near-ring dengan $I=\left\{\left(\begin{array}{ll}a & 0 \\ 0 & 0\end{array}\right) \mid a \in R, a+a=a\right\}$ adalah ideal semigrup dari $N$. Apabila pada $N$ didefinisikan derivasi $d\left(\left(\begin{array}{ll}a & 0 \\ 0 & 0\end{array}\right)\right)=\left(\begin{array}{ll}a & 0 \\ 0 & 0\end{array}\right)$ untuk setiap $\left(\begin{array}{cc}a & 0 \\ 0 & 0\end{array}\right) \in N$ maka derivasi ini memenuhi $d([A, B])=[A, B]$ untuk setiap $A, B \in I$. Prime near-ring ini merupakan ring komutatif.

Berikut disertakan pula contoh dari near-ring yang merupakan ring komutatif namun memenuhi syarat cukup pada Teorema 4.1, yaitu $\quad d([x, y])=[x, y]$ untuk setiap 
$x, y \in I$ meskipun near-ring tersebut bukan prime near-ring.

Contoh 4.3 Diberikan suatu ring komutatif $R$ yang tidak memuat pembagi nol. Himpunan $M=\left\{\left(\begin{array}{cc}a & 0 \\ 0 & b\end{array}\right) \mid a, b \in R, a+a=a\right\} \quad$ yang dilengkapi dengan operasi penjumlahan dan perkalian matriks biasa bukan prime near-ring dengan $I=\left\{\left(\begin{array}{ll}a & 0 \\ 0 & 0\end{array}\right) \mid a \in R\right\} \quad$ adalah ideal semigrup dari $M$. Pada $M$ didefinisikan derivasi $d\left(\left(\begin{array}{ll}a & 0 \\ 0 & b\end{array}\right)\right)=\left(\begin{array}{ll}a & 0 \\ 0 & 0\end{array}\right) \quad$ yang memenuhi $d([A, B])=[A, B]$ untuk setiap $A, B \in I$. Dapat dibuktikan dengan mudah bahwa $M$ merupakan ring komutatif.

Selain kedua contoh tersebut, berikut juga diberikan contoh dari near-ring yang bukan ring komutatif dan bukan prime near-ring namun memenuhi aksioma pada Teorema 4.1

Contoh 3.4 Diberikan ring $R$ yang tidak memuat pembagi nol. Himpunan $P=\left\{\left(\begin{array}{ll}a & b \\ 0 & 0\end{array}\right) \mid a, b \in R, a+a=a\right\} \quad$ yang dilengkapi dengan operasi penjumlahan dan perkalian matriks biasa bukan prime near-ring dengan $I=\left\{\left(\begin{array}{cc}a & b \\ 0 & 0\end{array}\right) \mid a, b \in R\right\} \quad$ adalah ideal semigrup dari $P$. Pada $P$ didefinisikan derivasi $d\left(\left(\begin{array}{ll}a & b \\ 0 & b\end{array}\right)\right)=\left(\begin{array}{ll}a & b \\ 0 & 0\end{array}\right) \quad$ yang memenuhi $d([A, B])=[A, B]$ untuk setiap $A, B \in I$. Dapat ditunjukkan dengan mudah bahwa $P$ bukan ring komutatif.

Syarat cukup bagi prime near-ring merupakan ring komutatif yang selanjutnya disajikan pada Teorema 3.5.

Teorema 3.5 (Boua, 2012) Diberikan prime near-ring $N$ dan ideal semigrup tak nol $I$ dari $N$. Jika $d$ derivasi tak nol pada $N$ yang memenuhi $d([x, y])=[d(x), y]$ atau $[x, y]=[d(x), y]$ untuk setiap $x, y \in I$, maka $N$ adalah ring komutatif.

\section{Bukti}

Diketahui $N$ prime near-ring, $I$ ideal semigrup tak nol dari $N$ dan $d$ derivasi tak nol pada $N$ yang memenuhi $d([x, y])=[d(x), y]$ atau $[x, y]=[d(x), y]$ untuk setiap $x, y \in I$. Diambil sebarang $x, y \in I$.

a) Berdasarkan asumsi pertama, berlaku $d([x, y])=[d(x), y]$. Dibentuk $x y$ lalu $x y$ disubstitusikan pada $y$, didapatkan

$$
d([x, x y])=[d(x), x y]
$$

Karena $[x, x y]=x[x, y]$, maka

$$
d(x[x, y])=[d(x), x y]
$$

Berdasarkan definisi derivasi, $d(x[x, y])$ dapat diuraikan menjadi $d(x[x, y])=x d([x, y])+$ $d(x)[x, y]$. Di lain pihak, dari definisi Lie Product diperoleh $[d(x), x y]=d(x) x y-$ $x y d(x)$. Oleh karena itu, berdasarkan hal tersebut dan dari asumsi, persamaan (7) dapat ditulis kembali menjadi

$$
\begin{gathered}
\quad x d([x, y])+d(x)[x, y] \\
=d(x) x y-x y d(x) \\
\Leftrightarrow x[d(x), y]+d(x)[x, y]=d(x) x y- \\
\quad x y d(x) \quad x y d(x)+d(x)(x y-y x) \\
\Leftrightarrow x d(x) y-x y d(x) x y-x y d(x) \\
\Leftrightarrow x d(x) y-x y d(x)+d(x) x y-d(x) y x \\
\quad=d(x) x y-x y d(x) \\
\Leftrightarrow x d(x) y-d(x) y x=0 \\
\Leftrightarrow x d(x) y=d(x) y x
\end{gathered}
$$

Selanjutnya, diambil sebarang $z \in N$. Dibentuk $y z$ lalu $y z$ disubstitusikan pada $y$ di persamaan (8), diperoleh

$$
\begin{aligned}
& x d(x) y z=d(x) y z x \\
\Leftrightarrow & d(x) y x z=d(x) y z x \\
\Leftrightarrow & d(x) y z x-d(x) y x z=0 \\
\Leftrightarrow & d(x) y(x z-z x)=0 \\
\Leftrightarrow & d(x) y[x, z]=0
\end{aligned}
$$

Karena $y$ adalah sebarang elemen pada $I$, maka persamaan (9) dapat ditulis menjadi $d(x) I[x, z]=0$. Dari hasil ini dan dengan menggunakan Lemma 1.7, persamaan tersebut mengimplikasikan bahwa $d(x)=0$ atau $[x, z]=0$. Karena $d$ adalah derivasi tak nol pada $N$ maka $d(x)=0$ tidak memenuhi. Oleh karena itu berlaku $[x, z]=0$. Hal ini berarti $x z=z x$ 
Karena $x \in I$ dan $z \in N$, maka berdasarkan definisi $Z(N), \quad x \in Z(N)$. Karena $x \in Z(N)$, maka $d(x) \in Z(N)$ untuk setiap $x \in I$. Hal ini berarti $d(I) \subset Z(N)$. Berdasarkan Lemma 1.6, sehingga didapatkan bahwa $N$ merupakan ring komutatif.

b) Berdasarkan asumsi kedua, berlaku $[d(x), y]=[x, y] . \quad$ Dibentuk $y x \quad$ dan substitusikan $y x$ pada $x$, didapatkan

$$
[d(y x), y]=[y x, y]
$$

Diperhatikan bahwa dari definisi Lie product, $[y x, y]=y x y-y y x=y(x y-y x)=y[x, y]$. Berdasarkan hal tersebut dan asumsi kedua, persamaan (10) menjadi

$$
\begin{aligned}
& {[d(y x), y]=y[x, y] } \\
\Leftrightarrow & {[d(y x), y]=y[d(x), y] } \\
\Leftrightarrow & d(y x) y-y d(y x)=y(d(x) y-y d(x)) \\
\Leftrightarrow & (y d(x)+d(y) x) y-y(y d(x)+ \\
& d(y) x)=y(d(x) y-y d(x)) \\
\Leftrightarrow & y d(x) y+d(y) x y-y y d(x)-y d(y) x= \\
& y d(x) y-y y d(x) \\
\Leftrightarrow & d(y) x y-y d(y) x=0 \\
\Leftrightarrow & d(y) x y=y d(y) x
\end{aligned}
$$

Selanjutnya, diambil sebarang $z \in N$. Dibentuk $x z$ dan substitusi $x z$ pada $x$ di persamaan (11), diperoleh

$$
\begin{aligned}
& d(y) x z y=y d(y) x z \\
\Leftrightarrow & d(y) x z y=d(y) x y z \\
\Leftrightarrow & d(y) x y z-d(y) x z y=0 \\
\Leftrightarrow & d(y) x(y z-z y)=0 \\
\Leftrightarrow & d(y) x[y, z]=0
\end{aligned}
$$

Karena $x$ adalah sebarang elemen pada $I$, maka persamaan (12) dapat ditulis menjadi $d(y) I[y, z]=0$. Dari hasil tersebut dan dengan menggunakan Lemma 1.7, persamaan tersebut mengimplikasikan bahwa $d(y)=0$ atau $[y, z]=0$. Karena $d$ adalah derivasi tak nol pada $N$ maka $d(y)=0$ tidak memenuhi. Oleh karena itu berlaku $[y, z]=0$. Hal ini berarti $y z=z y$.

Karena $y \in I$ dan $z \in N$, maka berdasarkan definisi $Z(N), \quad y \in Z(N)$. Karena $y \in Z(N)$, maka $d(y) \in Z(N)$ untuk setiap $y \in I$. Hal ini berarti $d(I) \subset Z(N)$. Berdasarkan Lemma 1.6, sehingga didapatkan bahwa $N$ merupakan ring komutatif.
Berikut diberikan contoh penerapan dari Teorema 3.5

Contoh 3.6 Diperhatikan prime near-ring $N$, ideal semigrup tak nol $I$ dari $N$, dan derivasi tak nol $d$ pada Contoh 3.2. Derivasi $d$ memenuhi (a) $d([A, B])=[d(A), B]$ atau (b) $[A, B]=$ $[d(A), B]$ untuk setiap $A, B \in I$ dan telah ditunjukkan bahwa $N$ adalah ring komutatif.

Berikut juga diberikan contoh dari near-ring yang merupakan ring komutatif namun bukan prime near-ring dan memenuhi syarat cukup pada Teorema 3.5.

Contoh 3.7 Mengacu pada near-ring $M$, ideal semigrup tak nol $I$ dari $M$, dan derivasi tak nol $d$ pada Contoh 4.3. Derivasi $d$ pada $M$ memenuhi (a) $d([A, B])=[d(A), B]$ atau (b) $[A, B]=$ $[d(A), B]$ untuk setiap $A, B \in I$. Telah ditunjukkan pula bahwa $M$ adalah ring komutatif.

Contoh dari near-ring yang bukan prime near-ring serta bukan ring komutatif namun memenuhi aksioma pada Teorema 3.5 diberikan pada Contoh 3.8 sebagai berikut

Contoh 3.8 Diperhatikan kembali near-ring $P$, ideal semigrup tak nol $I$ dari $P$, dan derivasi tak nol $d$ pada Contoh 3.4. Derivasi $d$ pada $P$ memenuhi (a) $d([A, B])=[d(A), B]$ atau (b) $[A, B]=[d(A), B]$ untuk setiap $A, B \in I$. Telah ditunjukkan bahwa $P$ bukan ring komutatif.

Pada Teorema 3.1 dan 3.5, syarat cukup prime near-ring merupaka ring komutatif melibatkan derivasi dan Lie product pada ideal semigrupnya. Berikut diberikan pula syarat cukup prime near-ring merupakan ring komutatif yang melibatkan derivasi dan Jordan product pada ideal semigrupnya seperti pada Teorema 3.9, Teorema 3.13 dan Teorema 3.17.

Teorema 3.9 (Boua, 2012) Diberikan prime near-ring $N$ dan ideal semigrup tak nol $I$ dari $N$. Jika $d$ derivasi tak nol pada $N$ yang memenuhi $d(x \diamond y)=x \diamond y$ untuk setiap $x, y \in I$, maka $N$ 
adalah ring komutatif.

\section{Bukti}

Diketahui $N$ prime near-ring, $I$ ideal semigrup tak nol dari $N$ dan $d$ derivasi tak nol pada $N$ yang memenuhi $d(x \diamond y)=x \diamond y$ untuk setiap $x, y \in I$. Diambil sebarang $x, y \in I$. Berdasarkan asumsi, berlaku $d(x \diamond y)=x \diamond y$. Dibentuk $y x$ dan substitusikan $y x$ pada $x$, didapatkan

$$
d(y x \diamond y)=y x \diamond y
$$

Diperhatikan bahwa berdasarkan definisi Jordan product diperoleh $y x \diamond y=y(x \diamond y)$. Dengan demikian persamaan (4.13) dapat ditulis menjadi

$$
d(y(x \diamond y))=y(x \diamond y)
$$

Berdasarkan definisi derivasi dan asumsi, $d(y(x \diamond y))$ dapat diuraikan menjadi

$$
d(y(x \diamond y))=y(x \diamond y)+d(y)(x \diamond y)
$$

Sehingga persamaan (14) dapat ditulis kembali menjadi

$$
\begin{aligned}
& y(x \diamond y)+d(y)(x \diamond y)=y(x \diamond y) \\
\Leftrightarrow & d(y)(x \diamond y)=0 \\
\Leftrightarrow & d(y)(x y+y x)=0 \\
\Leftrightarrow & d(y) x y+d(y) y x=0 \\
\Leftrightarrow & d(y) x y=-d(y) y x
\end{aligned}
$$

Selanjutnya, ambil sebarang $z \in N$. Dibentuk $x z$ dan substitusi $x z$ pada $x$ di persamaan (15) sehingga diperoleh

$$
\begin{aligned}
& d(y) x z y=-d(y) y x z \\
\Leftrightarrow & d(y) x z y=d(y) x y z \\
\Leftrightarrow & d(y) x z y-d(y) x y z=0 \\
\Leftrightarrow & d(y) x(z y-y z)=0 \\
\Leftrightarrow & d(y) x[z, y]=0
\end{aligned}
$$

Karena $x$ adalah sebarang elemen pada $I$, maka persamaan (16) dapat ditulis menjadi $d(y) I[z, y]=0$. Dari hasil tersebut dan dengan menggunakan Lemma 1.7, persamaan tersebut berarti $d(y)=0$ atau $[z, y]=0$. Karena berdasarkan asumsi $d$ adalah derivasi tak nol pada $N$ maka $d(y)=0$ tidak memenuhi. Oleh karena itu berlaku $[z, y]=0$. Hal ini berarti $z y=y z$.

Karena $y \in I$ dan $z \in N$, sehingga berdasarkan Definisi 1.3, $y \in Z(N)$. Karena $y \in Z(N)$, maka $d(y) \in Z(N)$ untuk setiap $y \in I$. Hal ini berarti $d(I) \subset Z(N)$. Berdasarkan
Lemma 1.6, maka sehingga didapatkan bahwa $N$ merupakan ring komutatif.

Contoh penerapan Teorema 3.9 disajikan seperti pada Contoh 3.10 berikut.

Contoh 3.10 Diperhatikan prime near-ring $N$, ideal semigrup tak nol $I$ dari $N$, dan derivasi tak nol $d$ pada Contoh 4.2. Derivasi $d$ pada $N$ memenuhi $d(A \diamond B)=(A \diamond B)$ untuk setiap $A, B \in I$.

Berikut merupakan contoh dari near-ring yang bukan prime near-ring tetapi memenuhi syarat cukup pada Teorema 3.9.

Contoh 3.11 Mengacu pada near-ring $M$, ideal semigrup tak nol $I$ dari $M$, dan derivasi tak nol $d$ pada Contoh 3.3. Derivasi $d$ memenuhi $d(A \diamond$ $B)=(A \diamond B)$ untuk setiap $A, B \in I$.

Contoh dari near-ring yang bukan prime near-ring serta bukan ring komutatif namun memenuhi aksioma pada Teorema 3.9 diberikan pada Contoh 3.12 sebagai berikut

Contoh 3.12 Diperhatikan kembali pada nearring $P$, ideal semigrup tak nol $I$ dari $P$, dan derivasi tak nol $d$ pada Contoh 3.4. Derivasi $d$ memenuhi $d(A \diamond B)=(A \diamond B)$ untuk setiap $A, B \in I$.

Syarat cukup prime near-ring merupakan ring komutatif yang melibatkan derivasi dan Jordan product pada ideal semigrupnya yang selanjutnya disajikan dalam Teorema 3.13

Teorema 3.13 (Boua, 2012) Diberikan prime near-ring $N$ dan ideal semigrup tak nol $I$ dari $N$. Jika $d$ derivasi tak nol pada $N$ yang memenuhi $d(x) \diamond y=x \diamond y$ untuk setiap $x, y \in I$, maka $N$ adalah ring komutatif.

\section{Bukti}

Diketahui $N$ prime near-ring, $I$ ideal semigrup tak nol dari $N$ dan $d$ derivasi tak nol pada $N$ yang memenuhi $d(x) \diamond y=x \diamond y$ untuk setiap , $y \in I$. Diambil sebarang $x, y \in I$. Berdasarkan asumsi, berlaku $d(x) \diamond y=x \diamond y$. Dibentuk $y x$ dan $y x$ disubstitusikan pada $x$, didapatkan 


$$
d(y x) \diamond y=(y x \diamond y)
$$

Diperhatikan bahwa berdasarkan definisi Jordan product, $y x \diamond y=y(x \diamond y)$. Dengan demikian persamaan (17) dapat ditulis kembali dan diuraikan menjadi

$$
\begin{aligned}
& d(y x) \diamond y=y(x \diamond y) \\
\Leftrightarrow & d(y x) y+y d(y x)=y(x \diamond y) \\
\Leftrightarrow & d(y x) y+y d(y x)=y(d(x) \diamond y) \\
\Leftrightarrow & (y d(x)+d(y) x) y+y(y d(x)+d(y) x) \\
& \quad=y(d(x) \diamond y) \\
\Leftrightarrow & y d(x) y+d(y) x y+y y d(x)+y d(y) x= \\
& y d(x) y+y y d(x) \\
\Leftrightarrow & d(y) x y++y d(y) x=0 \\
\Leftrightarrow & -y d(y) x=d(y) x y
\end{aligned}
$$

Selanjutnya, ambil sebarang $z \in N$. Dibentuk $x z$ dan substitusi $x Z$ pada $x$ di persamaan (18) sehingga diperoleh

$$
\begin{aligned}
& d(y) x z y=-y d(y) x z \\
& \Leftrightarrow d(y) x z y=d(y) x y z \\
& \Leftrightarrow d(y) x z y-d(y) x y z=0 \\
& \Leftrightarrow d(y) x(z y-y z)=0 \\
& \Leftrightarrow d(y) x[z, y]=0
\end{aligned}
$$

Karena $x$ adalah sebarang elemen pada $I$, maka persamaan (19) dapat ditulis menjadi $d(y) I[z, y]=0$. Dengan menggunakan Lemma 1.7 , persamaan tersebut berarti $d(y)=0$ atau $[z, y]=0$. Karena berdasarkan asumsi $d$ adalah derivasi tak nol pada $N$ maka $d(y)=0$ tidak memenuhi. Oleh karena itu berlaku $[z, y]=0$. Hal ini berarti $z y=y z$.

Karena $y \in I$ dan $z \in N$, sehingga berdasarkan Definisi 1.3, $y \in Z(N)$. Karena $y \in Z(N)$, maka $d(y) \in Z(N)$ untuk setiap $y \in I$. Hal ini berarti $d(I) \subset Z(N)$. Berdasarkan Lemma 1.6, maka sehingga didapatkan bahwa $N$ merupakan ring komutatif.

Berikut merupakan contoh penerapan dari Teorema 3.13

Contoh 3.14 Mengacu pada prime near-ring $N$, ideal semigrup tak nol $I$ dari $N$, dan derivasi tak nol $d$ pada Contoh 3.2. Derivasi $d$ memenuhi $d(A) \diamond B=(A \diamond B)$ untuk setiap $A, B \in I$.

Berikut merupakan contoh dari near-ring yang bukan prime near-ring tetapi memenuhi syarat cukup pada Teorema 3.13.
Contoh 3.15 Diperhatikan pada near-ring $M$, ideal semigrup tak nol $I$ dari $M$, dan derivasi tak nol $d$ pada Contoh 3.3. Derivasi $d$ memenuhi $d(A) \diamond B=(A \diamond B)$ untuk setiap $A, B \in I$.

Contoh dari near-ring yang bukan prime near-ring dan bukan ring komutatif tetapi memenuhi aksioma seperti pada Teorema 3.13 diberikan pada Contoh 3.16 berikut.

Contoh 4.16 Diperhatikan kembali near-ring $P$, ideal semigrup tak nol $I$ dari $P$, dan derivasi tak nol $d$ pada Contoh 3.4. Derivasi $d$ memenuhi $d(A) \diamond B=(A \diamond B)$ untuk setiap $A, B \in I$.

Pada Teorema 3.17 berikut juga dibahas syarat cukup prime near-ring merupakan ring komutatif yang melibatkan derivasi dan Jordan product pada ideal semigrupnya.

Teorema 3.17 (Boua, 2012) Diberikan prime near-ring $N$ dan ideal semigrup tak nol $I$ dari $N$. Jika $d$ derivasi tak nol pada $N$ yang memenuhi $d(x \diamond y)=d(x) \diamond y$ untuk setiap $x, y \in I$, maka $N$ adalah ring komutatif.

\section{Bukti}

Diketahui $N$ prime near-ring, $I$ ideal semigrup tak nol dari $N$ dan $d$ derivasi tak nol pada $N$ yang memenuhi $d(x \diamond y)=d(x) \diamond y$ untuk setiap $x, y \in I$. Diambil sebarang $x, y \in I$. Berdasarkan asumsi, berlaku $d(x \diamond y)=d(x) \diamond$ $y$. Dibentuk $x y$ dan substitusikan $x y$ pada $y$, didapatkan

$$
d(x \diamond x y)=d(x) \diamond x y
$$

Diperhatikan bahwa $x \diamond x y=x(x \diamond y)$. Dengan demikian persamaan (20) dapat ditulis kembali dan diuraikan menjadi

$$
\begin{aligned}
& d(x(x \diamond y))=d(x) \diamond x y \\
\Leftrightarrow & d(x(x \diamond y))=d(x) x y+x y d(x) \\
\Leftrightarrow & x d(x \diamond y)+d(x)(x \diamond y)=d(x) x y+ \\
& x y d(x) \\
\Leftrightarrow & x(d(x) \diamond y)+d(x)(x \diamond y)=d(x) x y+ \\
& x y d(x) \quad=d(x) x y+x y d(x) \\
\Leftrightarrow & x d(x) y+x y d(x)+d(x) x y+d(x) y x \\
\Leftrightarrow & x d(x) y+d(x) y x=0 \\
\Leftrightarrow & -x d(x) y=d(x) y x
\end{aligned}
$$

Selanjutnya ambil sebarang $z \in N$. Dibentuk $y z$ 
dan substitusi $y z$ pada $y$ di persamaan (21), diperoleh

$$
\begin{aligned}
& -x d(x) y z=d(x) y z x \\
\Leftrightarrow & d(x) y x z=d(x) y z x \\
\Leftrightarrow & d(x) y x z-d(x) y z x=0 \\
\Leftrightarrow & d(x) y(x z-z x)=0 \\
\Leftrightarrow & d(x) y[x, z]=0
\end{aligned}
$$

Karena $y$ adalah sebarang elemen pada $I$, maka persamaan (22) dapat ditulis menjadi $d(x) I[x, z]=0$. Dengan hasil tersebut dan menggunakan Lemma 1.7, persamaan tersebut berarti $d(x)=0$ atau $[x, z]=0 . \quad$ Karena berdasarkan asumsi $d$ adalah derivasi tak nol pada $N$ maka $d(x)=0$ tidak memenuhi. Oleh karena itu berlaku $[x, z]=0$. Hal ini berarti $x z=z x$.

Karena $\quad x \in I$ dan $z \in N$, sehingga berdasarkan Definisi 2.34, $x \in Z(N)$. Karena $x \in Z(N)$, maka $d(x) \in Z(N)$ untuk setiap $x \in I$. Hal ini berarti $d(I) \subset Z(N)$. Berdasarkan Lemma 1.6, maka sehingga didapatkan bahwa $N$ merupakan ring komutatif.

Contoh penerapan dari Teorema 3.17 diberikan pada Contoh 3.18 berikut.

Contoh 3.18 Dengan mengacu pada near-ring $N$, ideal semigrup tak nol $I$ dari $N$, dan derivasi tak nol $d$ pada Contoh 3.2 memenuhi $d(A \diamond B)=d(A) \diamond B$ untuk setiap $A, B \in I$.

Berikut merupakan contoh dari near-ring yang bukan prime near-ring tetapi memenuhi syarat cukup pada Teorema 3.17.

Contoh 3.19 Diperhatikan kembali near-ring $M$, ideal semigrup tak nol $I$ dari $M$, dan derivasi tak nol $d$ pada Contoh 3.3 memenuhi $d(A \diamond B)=d(A) \diamond B$ untuk setiap $A, B \in I$.

Contoh dari near-ring yang bukan prime near-ring dan bukan ring komutatif tetapi memenuhi aksioma seperti pada Teorema 3.17 diberikan pada Contoh 3.20 berikut.

Contoh 3.20 Diperhatikan near-ring $P$, ideal semigrup tak nol $I$ dari $P$, dan derivasi tak nol $d$ pada Contoh $3.4 \quad$ memenuhi $d(A \diamond B)=d(A) \diamond B$ untuk setiap $A, B \in I$.

\section{KESIMPULAN DAN SARAN}

Berdasarkan hasil dan pembahasan pada bagian sebelumnya, maka sehingga didapatkan bahwa hubungan antara derivasi prime near-ring dengan sifat komutatif ring adalah prime nearring merupakan ring komutatif adalah derivasi tak nol $d$ pada ideal semigrupnya memenuhi:(i) $d([x, y])=[x, y], \quad$ (ii) $\quad d([x, y])=[d(x), y]$, (iii) $d([x, y])=[x, y]$, (iv) $d(x \diamond y)=(x \diamond y)$, (v) $d(x) \diamond y=(x \diamond y)$, (vi) $d(x \diamond y)=d(x) \diamond$ $y$, untuk setiap $x, y \in I$, dengan $I$ adalah ideal semigrup tak nol dari prime near-ring $N$.

Pada penelitian selanjutnya, disarankan untuk mencari hubungan antara derivasi prime near-ring dengan sifat komutatif ring yang melibatkan ideal semigrupnya satu sisi. Selain itu, disarankan juga untuk mengganti derivasi yang digunakan dengan jenis derivasi lain, seperti Jordan derivasi, derivasi- $(\theta, \phi)$, dan derivasi yang telah diperumum.

\section{DAFTAR PUSTAKA}

Ashraf, M., \& Siddeeque, A. (2015). On Semigroup Ideals and Generalized nDerivation in Near-Rings. Sarajevo Journal Of Mathematics , 155-164.

Bell, H. E., \& Mason, G. (1987). On Derivation in Near-Rings. Elsevier Science Publisher B. V. (North-Holland), 31-35.

Bell, H. E., \& Mason, G. (1992). On Derivations in Near-Rings and Rings. Math. J. Okayama Univ , 135-144.

Boua, A. (2012). Some Conditions under which Prime Near-Rings are Commutative Rings. Int. J. Open Problems Compt. Math , 7-15.

Howie, J. M. (1976). An Introduction To Semigroup Theory. New York: Academic Press Inc. (London) Ltd.

Pilz, G. (1983). Near-Rings The Theory and its Applications. Amsterdam: North-Holland Publishing Company.

Wang, X.-K. (1994). Derivation in Prime NearRings. Proceedings of The American Mathematical Society, 361-366. 